\title{
The way insoluble fiber incorporated in the diet changes its physiological response
}

\author{
S. Hartini ${ }^{{ }^{*}}$, D.D. Rahardjo ${ }^{1}$ and H. Sasongko ${ }^{2}$ \\ ${ }^{1}$ Faculty of Animal Science, University of Papua, Manokwari 98314, Indonesia \\ ${ }^{2}$ Faculty of Animal Science, University of Gadjah Mada, Yogyakarta, Indonesia \\ *Corresponding E-mail : sri.hartini8877@gmail.com
}

Received August 18, 2020; Accepted July 10, 2021

\begin{abstract}
ABSTRAK
Efek fisiologis dari serat tak larut dapat berubah karena komposisi pakan. Penelitian bertujuan mengetahui perbedaan respon fisiologis ayam broiler yang diberi pakan yang dipadukan dengan sekam padi dengan cara yang berbeda. Dua ratus empat puluh ekor ayam broiler umur dua hari ditempatkan secara acak dalam 30 kandang dan diberi pakan: pakan kontrol (basis jagung-kedelai) (CO), pakan suplementasi sekam padi (CO + 4\% sekam padi) (RS), dan pakan inklusi sekam padi (inklusi 4\% sekam padi dalam pakan) (RI). Efek signifikan paling banyak ditemukan pada fase starter. RI meningkatkan ADG $(\mathrm{P}<0,05)$ tetapi menurunkan berat ceca kosong $(\mathrm{P}<0,05)$ dibandingkan dengan $\mathrm{CO}$ dan $\mathrm{RS} . \mathrm{RS}$ meningkatkan kedalaman kripta jejunum $(\mathrm{P}<0,05)$ dan menurunkan kandungan digesta usus halus $(\mathrm{P}<0,05)$. Ayam pedaging yang diberi pakan RS dan RI mempunyai villus yang lebih tinggi $(\mathrm{P}<0,05)$ dan mukosa jejunum yang lebih tebal $(\mathrm{P}<0,05)$ dibandingkan dengan yang diberi pakan $\mathrm{CO}$. Pada fase finisher, ayam pedaging yang diberi pakan RS memiliki lebar villi jejunal atas dan bawah yang lebih sempit daripada yang lain. Penambahan atau inklusi serat tidak larut ke dalam pakan menyebabkan respon fisiologis yang berbeda karena perubahan komposisi pakan.
\end{abstract}

Kata Kunci : bobot badan, kedalaman kripta, komposisi pakan, sekam padi, tinggi villus

\begin{abstract}
The physiological effect of insoluble fibers may change with diet composition. The present study aimed to determine the difference in the physiological responses of broiler chickens fed diet incorporated with rice hulls in different ways. Two hundred and forty broiler chicks at two-days old were randomly placed in 30 cages and fed: control diet (based on corn-soybean) (CO), rice hull supplementation $\operatorname{diet}(\mathrm{CO}+4 \%$ of rice hulls) (RS), and rice hull inclusion diet (inclusion of $4 \%$ rice hulls in diet) (RI). The significant effects were mostly found in the starter phase. The RI increased ADG $(\mathrm{P}<0.05)$ but reduced empty ceca weight $(\mathrm{P}<0.05)$ in comparison to $\mathrm{CO}$ and RS. The RS increased the jejunal crypt depth $(\mathrm{P}<0.05)$ and reduced the small intestinal content $(\mathrm{P}<0.05)$. Birds fed RS and RI had higher villus height $(\mathrm{P}<0.05)$ and thicker jejunal mucosa $(\mathrm{P}<0.05)$ than those fed the CO. In the finisher phase, birds fed the RS had the narrower width of the upper and lower jejunal villi than the others. Supplemen-
\end{abstract}


tation or inclusion of insoluble fiber in the diet will lead to different physiological responses due to changes in diet composition.

Keywords: ADG, crypt depth, diet composition, rice hulls, villus height

\section{INTRODUCTION}

The benefits of insoluble dietary fiber in broiler feed have been widely reported by previous researchers (Kheravii et al., 2018; JiménezMoreno et al., 2013a; Sacranie et al., 2012; Svihus et al., 2010), but in reality, each insoluble food fiber has a different physiological responses (Sadeghi et al., 2015; Alabi et al., 2014; Sacranie et al., 2012; Svihus et al., 2010). The level of insoluble dietary fiber in diet that provides benefits to broilers is also inconsistent (Svihus, 2011). On the other hand, age, strain, and composition of different rations were suggested to modify the effect of insoluble dietary fiber (Jiménez-Moreno et al., 2016).

The direct impact of providing insoluble feed fiber is the changes that occur in the small intestine, among others; changes in physiological function (Jiménez-Moreno et al., 2016; Sacranie et al., 2012), microbiota composition (Capuano, 2017), gut weight, and length (Yokhana et al., 2016; Sacranie et al., 2012; Jiménez-Moreno et al., 2009), and gut morphology (Rezaei et al., 2018; Adibmoradi et al., 2016; Nkukwana et al., 2015; Sarikhan et al., 2010). The small intestine will continue to experience changes both morphologically, biochemically, and molecularly after hatching (Bohórquez et al., 2011). Changes in intestinal morphology such as villous length (Adibmoradi et al., 2016; Rezaei et al., 2014; Sarikhan et al., 2010), villous thickness, and crypt depth (Rezai et al., 2018; Adibmoradi et al., 2016) are reported in broilers or quails fed insoluble dietary fiber. Any morphological changes that occur in the small intestine would affect its function, which eventually affects the function of other organs (Toman et al., 2015). The majority of digestion and absorption of all nutrients occurs in the jejunum, so morphological changes in the jejunum will have an impact on broiler performance.
Rice hulls, as an agricultural waste product from rice milling industries, contain a higher level of celluloses and lignin (Podolske et al., 2013). Although many researchers reported the rice hulls effects as a source of insoluble fibers in broiler chickens (Hartini et al., 2019; Sabour et al., 2019; Hartini and Purwaningsih, 2017; Abazari et al., 2016; Adibmoradi et al., 2016; Alabi et al., 2014), but there is a lack of information regarding the different physiological effect of rice hulls when supplemented or included in the diet. Therefore, this study was conducted to observe the different physiological responses i.e. performance, gastrointestinal traits, and jejunal morphologies of broiler chickens fed diet incorporated with rice hulls in different ways.

\section{MATERIALS AND METHODS}

Two hundred and forty two-day-old Lohmann chicks with an initial body weight of about $53.6 \mathrm{~g}$ (CV of 1.3\%) were assigned to groups of eight in 30 battery cages. Birds were given ad libitum feed and water until 35 days of age. The light was set out for 24 hours per day throughout the experiment. Three experimental diets used in the study were: 1 . corn and soybean meal base control diet (CO), 2. rice hull supplementation diet ( $\mathrm{CO}+4 \%$ of rice hulls) (RS), and 3. rice hull inclusion diet (inclusion of $4 \%$ rice hulls in diet) (RI). All diets were formulated to be iso-protein and were offered as mash. Besides iso -protein, the RS and RI were formulated to have a similar crude fiber level (around 5 to 5.5\%). Starter diets were offered until $21 \mathrm{~d}$ of age, at which point finisher diets were offered until the end of the experiment ( $35 \mathrm{~d}$ of age). The experimental diets and calculated nutrient composition are shown in Table 1.

The birds were weighed at the beginning of the experiment, at the end of the starter period (21 $\mathrm{d}$ of age), and at the end of the finisher period (35 
d of age). Feed consumption was recorded during the experiment. Average daily gain (ADG) (g/bird/d), feed consumption (FC) (g/bird/d), and efficiency of feed ratio (EFR) $(\mathrm{g} / \mathrm{g})$ were then calculated. Mortality was recorded when it hap- pened to allow correction to be made in calculating the FC and EFR.

At the end of starter and finisher periods, the birds were fasted for approximately seven hours. Two birds from each of the ten replicates

Table 1. Ingredient and Nutrient Composition of Experimental Diets (as-fed basis)

\begin{tabular}{|c|c|c|c|c|c|c|}
\hline \multirow[b]{2}{*}{ Ingredient, $\mathrm{g} / \mathrm{kg}$} & \multicolumn{3}{|c|}{ Starter diets } & \multicolumn{3}{|c|}{ Finisher diets } \\
\hline & $\mathrm{CO}$ & $\mathrm{RS}^{2)}$ & RI & $\mathrm{CO}$ & $\mathrm{RS}^{2)}$ & RI \\
\hline Corn & 527.4 & 527.4 & 355.7 & 617.8 & 617.8 & 371.0 \\
\hline Wheat bran & 87.9 & 87.9 & 161.7 & 52.9 & 52.9 & 162.2 \\
\hline DDGS & 78.9 & 78.9 & 76.3 & 83.8 & 83.8 & 80.8 \\
\hline Soybean meal & 128.5 & 128.5 & 120.9 & 89.3 & 89.3 & 100.2 \\
\hline $\begin{array}{l}\text { Poultry by-product } \\
\text { meal }\end{array}$ & 143.1 & 143.1 & 155.6 & 119.2 & 119.2 & 121.4 \\
\hline Palm oil & 6.2 & 6.2 & 63.8 & 11.1 & 11.1 & 99.8 \\
\hline Rice hulls & - & - & 40.0 & - & - & 40.0 \\
\hline $\mathrm{NaCl}$ & 3.3 & 3.3 & 3.3 & 2.2 & 2.2 & 2.2 \\
\hline Lysin & 0.3 & 0.3 & 0.1 & 1.1 & 1.1 & 1.0 \\
\hline DL-methionine & 1.1 & 1.1 & 1.2 & 0.3 & 0.3 & 0.4 \\
\hline Mineral Mix ${ }^{1)}$ & 5.0 & 5.0 & 5.0 & 5.0 & 5.0 & 5.0 \\
\hline $\mathrm{Ca}_{2} \mathrm{PO}_{4}$ & 12.7 & 12.7 & 11.4 & 11.0 & 11.0 & 9.5 \\
\hline $\mathrm{CaCO}_{3}$ & 5.6 & 5.6 & 5.0 & 6.3 & 6.3 & 6.5 \\
\hline Total & 100.0 & 100.0 & 100.0 & 100.0 & 100.0 & 100.0 \\
\hline \multicolumn{7}{|c|}{ Calculated nutrient, \% } \\
\hline ME (kcal/kg) & 3000 & 3154 & 3000 & 3100 & 3254 & 3100 \\
\hline Crude protein & 23 & 23 & 23 & 20 & 20 & 20 \\
\hline Crude fat & 4.7 & 4.7 & 10.3 & 5.2 & 5.2 & 13.7 \\
\hline Crude fiber & 3.1 & 5.1 & 5.5 & 2.8 & 4.8 & 5.5 \\
\hline $\mathrm{Ca}$ & 1.0 & 1.0 & 0.9 & 0.9 & 0.9 & 0.9 \\
\hline Total Phosphorus & 0.9 & 0.9 & 1.0 & 0.8 & 0.8 & 0.8 \\
\hline $\mathrm{Na}$ & 0.2 & 0.2 & 0.2 & 0.2 & 0.2 & 0.2 \\
\hline Lysin & 1.1 & 1.1 & 1.1 & 1.0 & 1.0 & 1.0 \\
\hline Methionine & 0.5 & 0.5 & 0.5 & 0.4 & 0.4 & 0.4 \\
\hline
\end{tabular}

\footnotetext{
${ }^{1)}$ Supplied per kg of diet (mg): vitamin A (retinol) 3.0, niacin 30.1, vitamin D3 (cholecalciferol) 0.05, folic acid 0.6, vitamin E 10.0, vitamin K 6.1, thiamin 3.2, riboflavin 12.0, pyridoxine 3.2, vitamin $\mathrm{B}_{12}$ 0.04, $\mathrm{Cu}$ 8.8, Co 1.0, Fe 93.6, I 4.8, Mn 163.2, Zn 120.0, Ca-d-pantothenate $20.0 .{ }^{2}$ Supplemented with rice hulls $40 \mathrm{~g} / \mathrm{kg}$ of diet
} 
were selected randomly, weighed, and slaughtered. The gastrointestinal tract (GIT), including the pancreas, was then removed. The aim of sampling was to weigh the gizzard, small intestine (from the end of the gizzard to the ileo-cecocolic junction), and ceca before and after removal of content. The pancreas was also weighed. The emptied weight of digestive organs was denoted as $\mathrm{g} / 100 \mathrm{~g} \mathrm{BW}$ (without digesta), whereas the content of gizzard, intestinal, and ceca were set as $\mathrm{g} / 100 \mathrm{~g} \mathrm{BW}$.

To measure the jejunal morphology, two centimeters of the jejunum samples with content were cut adjacent to Meckel's diverticulum. Samples were stored in $10 \%$ buffered neutral formalin for fixation. Samples were manually sectioned with a microtome to obtain 4-5 $\mu \mathrm{m}$ thick sections, placed on glass slides, stained with hematoxylin-eosin, and then examined by light microscopy. The histology observations made were villus height (VH), upper villus width (UVW), lower villus width (LVW), crypt depth (CD), and mucosa thickness (MT). The calculation was made to get the $\mathrm{VH}: \mathrm{CD}$ ratio.

Data were analyzed by one-way analysis of variance of completely randomized design (SPSS 25.0). When the F test was significant, mean differences among the group were inspected using the Duncan's multiple range test. A significant effect was accepted at level of 5\%.

\section{RESULTS AND DISCUSSION}

In this study, to get a similar level of protein and crude fiber of the rice hull inclusion diet with the rice hull supplementation diet, the level of wheat bran and the level of palm oil of the rice hull inclusion diet was increased about 2 and 10 times, respectively. Wheat bran is a concentrated source of insoluble fiber (Stevenson et al., 2012). The proportions of insoluble and soluble fiber in wheat bran are approximately $42 \%$ and $3 \%$, respectively (Vitaglione et al., 2008). Consequently, in addition to fat level, the rice hull inclusion diet obtains a higher concentration of insoluble fiber along with $40 \mathrm{~g} / \mathrm{kg}$ rice hulls than the other diets. While the higher insoluble fiber was reported to increase the rate of digesta passage (Hetland et al., 2004), the higher dietary fat was reported to slow down the digesta passage of broilers (Latshaw, 2008).

The effect of treatment diets on broilers performance is presented in Table 2 . The effect of treatment diets was significant during the starter period but not in the finisher period. The rice hull inclusion diet increased ADG about 5\% and $8 \%$ higher than the control and the rice hull supplementation diets, respectively, but did not affect feed consumption and EFR. This result is in contrast with Jimenéz-Moreno et al. (2016), who found that the inclusion of rice hulls up to $5 \%$ in broiler diets had no effects on ADG, feed consumption, and feed conversion ratio at $21 \mathrm{~d}$ of age. On the other hand, Adibmoradi et al. (2016) reported that the inclusion of $1.5 \%$ rice hulls in broiler diets increased feed consumption at $24 \mathrm{~d}$ of age and increased feed consumption and ADG at $42 \mathrm{~d}$ of age. Moreover, Sadeghi et al. (2015) reported that $3 \%$ of rice hull inclusion in broiler diets had no effect on performance either at $24 \mathrm{~d}$ or $42 \mathrm{~d}$ of age. The findings of various authors and our data suggested that the physiological effect of insoluble fiber was not due to its level but it is more likely due to diet composition, age, and growth potential of broiler (Jimenéz-Moreno et al., 2016). According to Hartini et al. (2019), an interaction between insoluble fiber and other feed components in diet would modify the physicochemical properties of an individual fiber. After $15 \mathrm{~d}$ of age, the GIT of the birds starts to develop and obtain its maturity (Sklan, 2001), therefore the older the birds the higher their capability to digest fiber. This might explain the non-significant result found in the finisher period.

The effects of diets on the relative weight of digestive organs and content varied and were only significant during the starter period (Table 2). The rice hull inclusion diet decreased the relative weight of ceca as compared with the rice hull supplementation or the control diets. There are suggestions that the reduction in the weight of ceca was due to little or no microorganism activities that happened in the ceca. Activities of 
microorganisms in the ceca will increase with increasing fermentative substrates in the ceca, resulting in an increase the weight of the empty ceca (Jozefiak et al., 2006). The rice hull diet contains a high level of insoluble fibers and monogastric species lack specific microorganism species to ferment insoluble fiber (Hetland et al., 2004, Jha et al., 2010). A less fermentable diet would not support the proliferation or the activities of microorganisms in the ceca.

The result showed that the weight of the gizzard, small intestine, and pancreas was not affected by treatment diets. This result was similar to Hartini et al. (2013), who reported that the
GIT weight including gizzard, pancreas, and part of the small intestine was not affected by the addition of rice hull up to $6 \%$ in the diet based on corn and soybean. Sadeghi et al. (2015) and Incharoen (2013) also reported no increase in gizzard weight by the inclusion of rice hulls at $3 \%$ and $10 \%$, respectively. However, GonzaleźAlvarado et al. (2007) found there was an increase in gizzard weight by including $3 \%$ oat hulls in the diet. This result implies that besides levels and particle size (Svihus, 2011), the structure and the source of insoluble fibers contribute to their physicochemical properties (Mateos et al., 2012; Gonzaleź-Alvarado et al., 2008). Oat

Table 2. Growth performance, Gastrointestinal Traits and Jejunum Morphology of Broiler Chickens

\begin{tabular}{|c|c|c|c|c|c|c|c|c|c|c|}
\hline \multirow[b]{2}{*}{ Variables } & \multicolumn{3}{|c|}{$21 \mathrm{~d}$ of age } & \multicolumn{7}{|c|}{$35 \mathrm{~d}$ of age } \\
\hline & $\mathrm{CO}$ & $\mathrm{RS}$ & RI & SEM & p-value & $\mathrm{CO}$ & $\mathrm{RS}$ & RI & SEM & $p$-value \\
\hline ADG (g/b/d) & $29^{\mathrm{ab}}$ & $28^{\mathrm{a}}$ & $31^{\mathrm{b}}$ & 0.375 & $*$ & 43 & 41 & 44 & 0.547 & ns \\
\hline $\mathrm{FC}(\mathrm{g} / \mathrm{b} / \mathrm{d})$ & 46 & 45 & 47 & 0.558 & ns & 79 & 77 & 81 & 0.850 & $\mathrm{~ns}$ \\
\hline EFR & 0.64 & 0.63 & 0.66 & 0.080 & $\mathrm{~ns}$ & 0.54 & 0.54 & 0.55 & 0.006 & ns \\
\hline \multicolumn{11}{|l|}{ Weight of: } \\
\hline Empty Gizzard & 2.2 & 2.4 & 1.9 & 0.100 & ns & 1.6 & 1.6 & 1.4 & 0.064 & ns \\
\hline Empty SI & 3.2 & 3.5 & 2.8 & 0.141 & ns & 2.4 & 2.2 & 2.4 & 0.079 & $\mathrm{~ns}$ \\
\hline Empty Ceca & $0.3^{\mathrm{b}}$ & $0.3^{\mathrm{b}}$ & $0.2^{\mathrm{a}}$ & 0.03 & $*$ & 0.3 & 0.2 & 0.3 & 0.014 & ns \\
\hline Pancreas & 0.4 & 0.3 & 0.3 & 0.07 & ns & 0.2 & 0.2 & 0.2 & 0.014 & ns \\
\hline \multicolumn{11}{|l|}{ Content of: } \\
\hline Gizzard & 1.1 & 0.9 & 1.0 & 0.05 & ns & 1.0 & 0.9 & 0.9 & 0.049 & ns \\
\hline Small Intestine & $5.2^{\mathrm{b}}$ & $3.2^{\mathrm{a}}$ & $5.1^{\mathrm{b}}$ & 0.332 & $*$ & 1.8 & 1.4 & 1.5 & 0.130 & $\mathrm{~ns}$ \\
\hline Ceca & 0.4 & 0.4 & 0.3 & 0.039 & ns & 0.4 & 0.3 & 0.4 & 0.06 & ns \\
\hline \multicolumn{11}{|c|}{ Jejunum morphology $(\mu \mathrm{m})$ : } \\
\hline VH & $512^{\mathrm{a}}$ & $665^{\mathrm{b}}$ & $662^{\mathrm{b}}$ & 28.3 & $*$ & 485 & 514 & 658 & 47.0 & ns \\
\hline UVW & 115 & 121 & 103 & 7.91 & ns & $234^{b}$ & $72.6^{\mathrm{a}}$ & $164^{\mathrm{ab}}$ & 27.2 & * \\
\hline LVW & 110 & 140 & 128 & 15.7 & ns & $284^{\mathrm{b}}$ & $96.3^{\mathrm{a}}$ & $185^{\mathrm{ab}}$ & 33.0 & * \\
\hline $\mathrm{CD}$ & $145^{\mathrm{a}}$ & $218^{\mathrm{b}}$ & $148^{\mathrm{a}}$ & 14.1 & $*$ & 110 & 180 & 167 & 19.8 & ns \\
\hline MT & $622^{\mathrm{a}}$ & $823^{\mathrm{b}}$ & $822^{b}$ & 37.5 & $*$ & $578^{\mathrm{a}}$ & $800^{\mathrm{b}}$ & $796^{\mathrm{b}}$ & 42.2 & $*$ \\
\hline VH:CD ratio & 4.0 & 3.3 & 5.1 & 0.48 & ns & 5.5 & 3.3 & 4.2 & 0.68 & ns \\
\hline
\end{tabular}

VH: Villus height, UVW: Upper Villus Width, LVW: Lower Villus Width, CD: Crypt Depth, MT: Mucosa Thickness, ${ }^{*}=$ significant $(\mathrm{P}<0.05) ; \mathrm{ns}=$ non significant $(\mathrm{P}>0.05)$ 


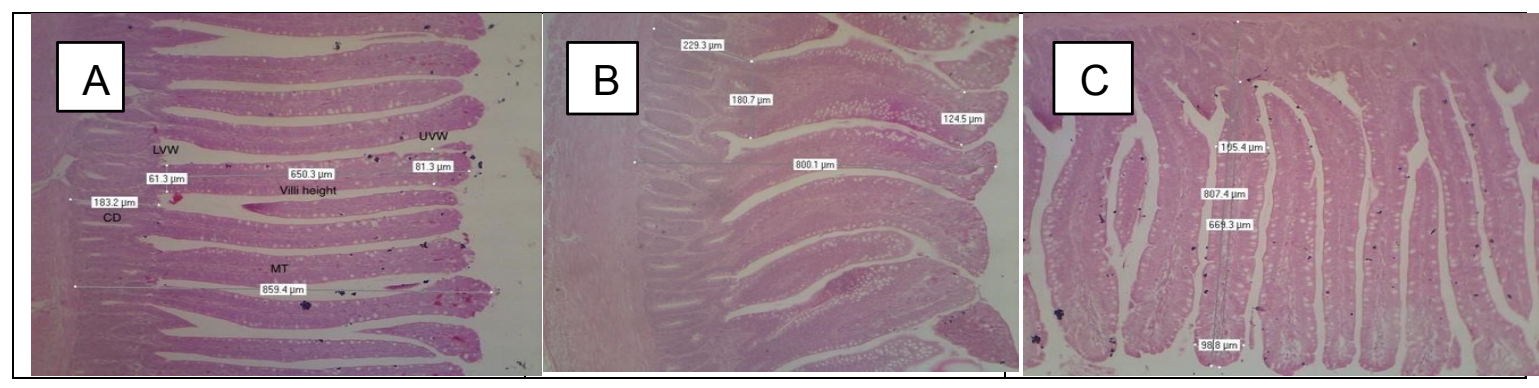

Figure 1. The representation of histological of the jejunal villi of broiler chickens at 21 $\mathrm{d}$ of age from the control diet (A), the rice hull supplementation diet (B), and the rice hull inclusion diet (C) (Hematoxylin and Eosin; $\mathrm{x} 40$ )

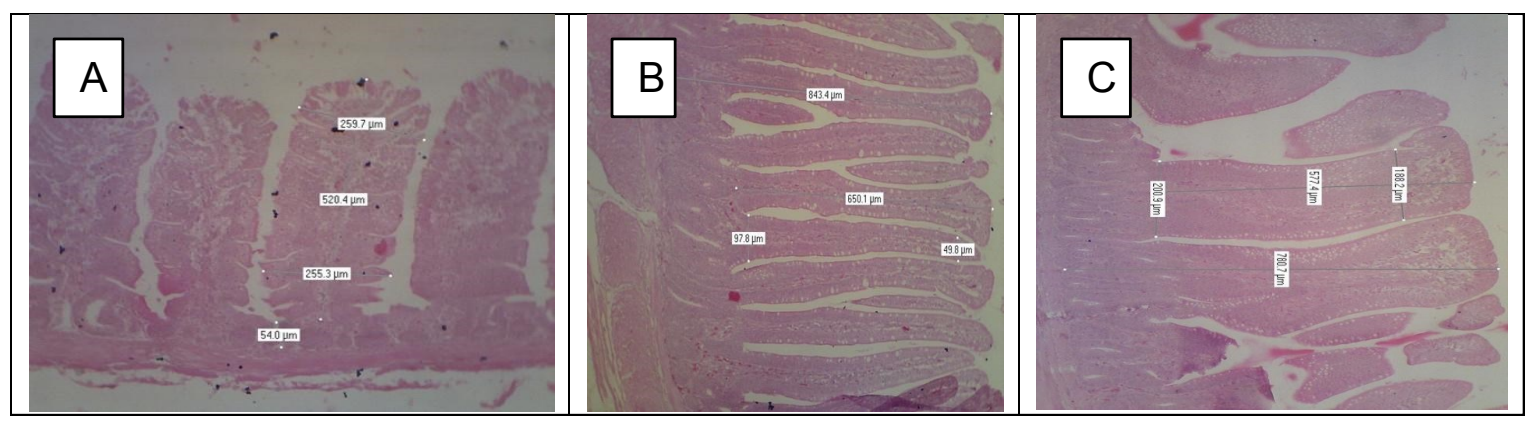

Figure 2. The representation of histological of the jejunal villi of broiler chickens at 35 $\mathrm{d}$ of age from the control diet (A), the rice hull supplementation diet (B), and the rice hull inclusion diet (C) (Hematoxylin and Eosin; $\mathrm{x} 40$ )

hulls were higher in hemicelluloses while rice hulls were higher in celluloses and lignin (Podolske et al., 2013). In addition, water absorption from cellulose extraction of oat hulls was higher than rice hulls (392.1\% vs $141.6 \%)$ (de Oliveira et al., 2016). All of these differences will affect the characteristic of the diet which eventually affects the response of fiber inclusion on GIT weight (Mateos et al., 2012).

The small intestine content significantly increased in birds fed the rice hull inclusion and control diets, the result that is not consistent with Hetland et al. (2004) who reported that high insoluble fiber diets would increase the rate of digesta passage, resulting in less digesta in the small intestine. Our result indicates that the magnitude of the response may be due to the higher fat level in the rice hull contained diet. Latshaw (2008) reported that the higher dietary fat slow down the digesta passage of broilers, thereby increasing nutrient utilization. Thus, the physiological function of the rice hull was interrupted by a higher fat level of diet, eventually slowing down the digesta passage and elevating nutrient utilization. This leads to an increase in the daily gain of young broilers as shown in our result. Mandey et al. (2017) also reported a good value of carcass percentage in broilers fed a diet containing $11 \%$ of crude fiber and about $11 \%$ of fat level.

The data on jejunal morphology traits of broilers are shown in Table 2. The jejunum villus height (VH) and mucosa thickness significantly increased by rice hull supplementation or inclusion diets than the control group. The finding is in agreement with Rezaei et al. (2014), who reported that the inclusion of $3 \%$ raw rice hull in the diet increased villous height in the jejunum of broilers. Moreover, Rezaei et al. (2018) observed an increase in jejunal villous height due to mi- 
cronized wheat fiber addition in the control feed. However, some authors have demonstrated that the addition or inclusion of rice hulls decreased jejunal villus height in broilers (Sabour et al., 2019; Abazari et al., 2016; Adibmoradi et al., 2016; Incharoen, 2013). The varied effect of dietary fiber on epithelial morphology depends on the physico-chemical properties of the fibers, the incorporation level of fibers in the diet, the length of the feed given, the species of animal and age (Montagne et al., 2003), and the composition of the diet (Mateos et al., 2012).

The villus height and villus surface area (Rezaei et al., 2014; Teirlynck et al., 2009), mucosa thickness (Jiménez-Moreno et al., 2013b), and crypt depth (CD) (Markovicva et al., 2009) of the jejunum reflect its capacity for nutrient absorption. A higher villus height and wider villus surface area are associated with greater capacity of nutrient absorption (Rezaei et al., 2014), whereas a deeper jejunal crypt is referred to an increase in intestinal maintenance, thus consuming energy and protein that is used in muscle deposition (Markovicva et al., 2009). In the present study, the value of the VH:CD ratio in birds fed the rice hull inclusion diets was higher than the others, whereas birds fed the rice hull supplementation diet showed a significantly higher value in the crypt depth. This might explain the lower daily gain observed in birds fed the rice hull supplementation diet in the starter period.

At $35 \mathrm{~d}$ of age birds fed the rice hull supplementation diet reduced the width of upper and lower jejunal villi. However, the mucosa thickness in birds fed either rice hull supplementation or inclusion diets was higher than the control diet. Therefore, although the villus surface area in birds fed the rice hull supplementation diet was reduced, the function of the intestinal mucosa was not affected (Jiménez-Moreno et al., 2013b), as shown by no significant effect of daily gain among diets in the finisher period. The representation of histological of the jejunal villi of broiler chickens at $21 \mathrm{~d}$ of age and $35 \mathrm{~d}$ of age from all the groups are shown in Figures 1 and 2.

\section{CONCLUSION}

Rice hull supplementation diet caused an increase in villus height and mucosa thickness, but a deeper crypt, resulting in poor performance of younger broiler chickens. In contrast, the rice hull inclusion diet increased villus height, mucosa thickness, and showed a higher value of $\mathrm{VH}: \mathrm{CD}$ ratio, resulting in greater body weight gain. The way insoluble fiber is incorporated into the diet will lead to different physiological responses due to changes in diet composition. The physiological response was pronounced in younger broiler chickens but not in older age.

\section{ACKNOWLEDGMENTS}

The present study could be carried out due to the financial assistance from the Ministry of Research and Technology of Higher Education of the Republic of Indonesia through contract No. 080/SP2H/L. T/DRPM/2018 from the National Competitive Fund, Competency-based Research. Extended thank was delivered to PT. Japfa Comfeed Tbk for help in providing the feedstuffs used in this study.

\section{REFERENCES}

Abazari, A., B. Navidshad, F.M. Aghjehgheshlagh and S. Nikbin. 2016. The effect of rice husk as an insoluble dietary fiber source on intestinal morphology and Lactobacilli and Escherichia coli populations in broilers. Iran J. Vet. Med. 10 (3): 217-224.

Adibmoradi, M., B. Navidshad and M.F. Jahromi. 2016. The effect of moderate levels of finely ground insoluble fibre on small intestine morphology, nutrient digestibility and performance of broiler chickens. Ital. J. Anim. Sci. 15 (2): 310-317.

Alabi, O.O., J.O. Atteh and P.T. Ogunniyi. 2014. Effect of dietary inclusion of rice husk supplemented with commercial enzymes on performance, nutrient retention and gastrointestinal tract characteristics of Ar- 
bor Acres broilers. Am. J. Exp. Agric. 4 (5): 575-583.

Bohórquez, D.V., N.E. Bohórquez and P.R. Ferket. 2011. Ultrastructural development of the small intestinal mucosa in the embryo and turkey poult: A light and electron microscopy study. Poult. Sci. 90: 842-855.

Capuano, E. 2017. The behavior of dietary fiber in the gastrointestinal tract determines its physiological effect. Crit. Rev. Food Sci. Nutr. 57 (16): 3543-3564.

de Oliveira, J.P., G.P. Bruni, K.O. Lima, S.L.M.E. Halal, G.S. Rosa, A.R.G. Dias and E.R. Zavareze. 2016. Cellulose fibers extracted from rice and oat husks and their application in hydrogel. Food Chem. 22: 153-160.

Gonzaleź-Alvarado, J.M., E. Jiménez-Moreno and G.G. Mateos. 2007. Effect of type of cereal, heat processing of cereal, and inclusion of fiber in the diet on productive performance and digestive traits of broilers. Poult. Sci. 86: 1705-1715.

Gonzaleź-Alvarado, J.M., E. Jiménez-Moreno, D.G. Valencia, R. Lazaro and G.G. Mateos. 2008. Effects of fiber source and heat processing of the cereal on the development and $\mathrm{pH}$ of the gastrointestinal tract of broilers fed diets based on corn or rice. Poult. Sci. 87: 1779-1795.

Hartini, S. and P. Purwaningsih. 2017. Effects of adding insoluble non-starch polysaccharides and exogenous enzymes to a commercial broiler diet on the growth performance and carcass weight of broiler chickens. Pak. J. Nutr. 16 (4): 227-235.

Hartini, S., D.D. Rahardjo and P.Purwaningsih. 2019. The effect of rice hull inclusion and enzyme supplementation on the growth performance, digestive traits, dry matter and phosphorus content of intestinal digesta and feces of broiler chickens. Int. J. Poult. Sci. 18 (1): 21-27.

Hartini, S., M. Kayadoe and D.D. Rahardjo. 2013. Performance and digestive tract development of young broiler chickens fed mash basal diet supplemented with rice hull or wheat pollard at different levels. J. Indonesian Trop. Animal. Agric. 28 (4): 233-238.

Hetland, H., M. Choct and B. Svihus. 2004. Role of insoluble non-starch polysaccharides in poultry nutrition. World's Poult. Sci. J. 60: 415-422.

Incharoen, T. 2013. Histological adaptations of the gastrointestinal tract of broilers fed diet containing insoluble fiber from rice hull meal. Am. J. Anim. Vet. Sci. 8(2): 79-88. doi:10.3844/ajavssp.2013.79.88

Jha, R., B. Rossnagel, R. Pieper, A. Van Kessel and P. Leterne. 2010. Barley and oat cultivars with diverse carbohydrate composition alter ileal and total tract nutrient digestibility and fermentation metabolites in weaned piglets. Animal 4: 724-731.

Jiménez-Moreno, E., J.M. González-Alvarado, A. González-Serrano, R. Lázaro and G.G. Mateos. 2009. Effect of dietary fiber and fat on performance and digestive traits of broilers from one to twenty-one days of age. Poult. Sci. 88: 2562-2574.

Jiménez-Moreno, E., E.M. Frikha, A. de CocaSinova, J. Garcia and G.G. Mateos. 2013a. Oat hulls and sugar beet pulp for broiler diets: 1. Effects on growth performance and nutrient digestibility. Anim. Feed Sci. and Technol. 182: 33-43.

Jiménez-Moreno, E., M. Frikha, A. de CocaSinova, R.P. Lazaro and G.G. Mateos. 2013b. Oat hulls and sugar beet pulp in diets for broilers 2. Effects on the development of the gastrointestinal tract and on the structure of the jejunal mucosa. Anim. Feed Sci. Technol. 182: 44-52.

Jiménez-Moreno, E., A. de Coca-Sinova, J.M. González-Alvarado and G.G. Mateos. 2016. Inclusion of insoluble fiber sources in mash or pellet diets for young broilers. 1. Effects on growth performance and water intake. Poult. Sci. 95: 41-52.

Jozefiak, D., A. Rutkowski, B.B. Jensen and R.M. Engberg. 2006. The effect of $\beta$ glucanase supplementation of barley- and oat-based diets on growth performance 
and fermentation in broiler chicken gastrointestinal tract. Br. Poult. Sci. 51: 546557.

Kheravii, S.K., R.A. Swick, M. Choct and S.B. Wu. 2018. Effect of oat hulls as a free choice feeding on broiler performance, short chain fatty acids and microflora under a mild necrotic enteritis challenge. Anim. Nutr. 4: 65-72.

Latshaw, J. D. 2008. Daily energy intake of broiler chickens is altered by proximate nutrient content and form of the diet. Poult. Sci. 87 (1): 89-95.

Mandey, J.S., Y.H.S. Kowel, M.N. Regar and J.R. Leke. 2017. Effect of different level of energy and crude fiber from sawdust in diets on carcass quality of broiler. J. Indonesian Trop. Animal. Agric. 42 (4): 240246.

Markovicva, R., D. Sefera, M. Krsticvb and Petrujkicva. 2009. Effect of different growth promoters on broiler performance and gut morphology. Arch. Med. Vet. 41: 163-169.

Mateos, G.G., A. Jiménez-Moreno, M.P. Serrano and R.P. Lázaro. 2012. Poultry response to high levels of dietary fiber sources varying in physical and chemical characteristics. J. Appl. Poult. Res. 21: 156-174.

Nkukwana, T.T., V. Muchenje, P.J. Masika and B. Mushonga. 2015. Intestinal morphology, digestive organ size and digesta $\mathrm{pH}$ of broiler chickens fed diets supplemented with or without Moringa oleifera leaf meal. S. Afr. J. of Anim. Sci. 45 (4): 362370.

Podolske, J., S.S. Cho, R. Gonzalez, A.W. Lee and C. Peterson. 2013. Rice hull fiber: Food applications, physiological benefits, and safety. Cereals Foods World 58 (3): 127-131.

Rezaei, M., M.A.K. Torshizi and F. Shariatmadari. 2014. Inclusion of processed rice hulls as insoluble fiber in the diet on performance and digestive traits of japanese quails. J. Anim. Sci. Adv. 4 (7): 962-972.
Rezaei, M., M.A.K. Torshizi, H. Wall and E. Ivarsson. 2018. Body growth, intestinal morphology and microflora of quail on diets supplemented with micronised wheat fibre. Br. Poult. Sci. 59 (4): 422-429.

Sabour, S., S.A. Tabeidian and G. Sadeghi. 2019. Dietary organic acid and fiber sources affect performance, intestinal morphology, immune responses and gut microflora in broilers. Anim. Nutr. 5: 156-162.

Sacranie, A., B. Svihus, V. Denstadli, B. Moen, P.A. Iji and M.Choct. 2012. The effect of insoluble fiber and intermittent feeding on gizzard development, gut motility, and performance of broiler chickens. Poult. Sci. 91 (3): 693-700.

Sadeghi, A., M. Toghyani and A. Gheisari. 2015. Effect of various fiber types and choice feeding of fiber on performance, gut development, humoral immunity, and fiber preference in broiler chicks. Poult. Sci. 94: 2734-2743.

Sarikhan, M., H.A. Shahryar, B. Gholizadeh, M.H. Hosseinzadeh, B. Beheshti and A. Mahmoodnejad. 2010. Effects of insoluble fiber on growth performance, carcass traits and ileum morphological parameters on broiler chick males. Int. J. Agric. Biol. 12: 531-536. ISSN Online: 1814-9596. 10077/MSA/2010/12-4-531-536.

Sklan, D. 2001. Development of the digestive tract of poultry. World's Poult. Sci. J. 57: 415-428.

SPSS 25.0. 2007 Command Syntax Reference, SPSS Inc. (Chicago Ill.)

Stevenson, L., F. Phillips, K. O'Sullivan and J. Walton. 2012. Wheat bran: its composition and benefits to health, a European perspective. Int. J. Food Sci. Nutr. 63(8): 10011013.

Svihus, B., A. Sacranie, V. Denstadli and M. Choct. 2010. Nutrient utilization and functionality of the anterior digestive tract caused by intermittent feeding and inclusion of whole wheat in diets for broiler chickens. Poult. Sci. 89: 2617-2625.

Svihus, B. 2011. The gizzard: function, influence 
of diet structure and effects on nutrient availability. World's Poult. Sci. J. 67: 207 -223 .

Teirlynck, E., L. Bjerrum, V. Eeckhaut, G. Huygebaert, F. Pasmans, F. Haesebrouck, J. Dewulf, R. Ducatelle and F. Van Immerseel. 2009. The cereal type in feed influences gut wall morphology and intestinal immune cell infiltration in broiler chickens. Br. J. Nutr. 102: 1453-1461.

Toman, R., Z. Hajkova and S. Hluchy. 2015. Changes in intestinal morphology of rats fed with different levels of bee pollen.
Pharmacogn. Commn. 5: 261-264.

Vitaglione, P., A. Napolitano and V. Fogliano. 2008. Cereal dietary fibre: a natural functional ingredient to deliver phenolic compounds in the gut. Trends Food Sci. Tech. 19: 451-463.

Yokhana, J. S., G. Parkinson and T. L. Frankel. 2016. Effect of insoluble fiber supplementation applied at different ages on digestive organ weight and digestive enzymes of layer-strain poultry. Poult. Sci. 95: 550559. 